Pre-print version of a book chapter accepted for publication by Routledge in Day, A. ed. Religion and the 1 Individual: Belief, Practice, and Identity. Aldershot: Ashgate, pp. 157-168.

\title{
Religion and the Individual: A Socio-Legal Perspective
}

\author{
Russell Sandberg
}

The question of whether and how religion ought to be defined has long engaged both academics and lawyers (See, for example, the volumes edited by Idinopulos and Wilson (1998) and Platvoet and Molendijk (1999)). Weber and Durkheim put forward contrasting views as to the usefulness of a definition of 'religion'. Whilst Weber contended that "definition can be attempted, if at all, only at the conclusion of the study" (1965), Durkheim argued that a preliminary definition was required in order to "avoid focussing by mistake on ideas and practices that are not religious or conversely overlooking genuinely religious phenomena $(2001,25) .{ }^{1}$ Durkheim's rationale for a preliminary definition is as persuasive for the practicing lawyer as it is for the scholar (Sandberg, 2006b, forthcoming). In both cases, a definition serves as a basis of inclusion and exclusion. Certain groups are not studied by the scholar or denied legal protection on the grounds that they are not 'religions'.

Furthermore, the preliminary definition outlined by Durkheim in The Elementary Forms of Religious Life may be of use to lawyers in that the juxtaposition of legal texts with Durkheim's definition may reveal the often implicit presumptions and prejudices present in the law. Laws employ various definitions and conceptions of 'religion' which often contradict each other, even within the same jurisdiction. Studying State law in this way enables a greater understanding of the perception of 'religion' held by the State whilst studying religious law (the rules and regulatory instruments of religious groups) in this manner may reveal an insight into how those groups perceive themselves, their own identity and their relationship with other religious groups and the State. This piece focuses upon one definitional attribute of a 'religion' identified by Durkheim in The Elementary Forms of Religious Life: namely his assertion that religion is "eminently collective" $(2002,46)$. After elucidating the importance of this requirement to Durkheim's definition of religion, this piece examines whether State laws support 
Pre-print version of a book chapter accepted for publication by Routledge in Day, A. ed. Religion and the 2 Individual: Belief, Practice, and Identity. Aldershot: Ashgate, pp. 157-168.

Durkheim's claim, refute it or suggest a different understanding. This examination will begin with the most important State laws on religion: human rights guarantees common to many jurisdictions and constitutional provisions unique to specific jurisdictions. This will be followed by a discussion of particular laws in England and Wales. This legal evidence provides a previously unexplored dimension of the sociological debate since Durkheim: namely, whether is religion now largely a public or private affair (Hill, 1973, James, 1982). Furthermore, what follows will constitute an exploratory examination of how sociological works, such as those of Durkheim, may enable a greater understanding of legal texts on religion (Doe, 2004; this is developed further in Sandberg, forthcoming).

As is well known, in The Elementary Forms of Religious Life, Durkheim defined a 'religion' as "a unified system of beliefs and practices relative to sacred things, that is to say, things set apart and surrounded by prohibitions - beliefs and practices that unites its adherents in a single moral community called a church" $(2001,46)$. Durkheim thus puts forward a two stage definition. The first stage is that there needs to be "beliefs and practices relative to sacred things". However, this is not sufficient. As Durkheim noted, the definition is "not yet complete since it applies equally to two orders of things which, though related, must none the less be distinguished: magic and religion" $(2002,41)$. For Durkheim, a distinction between 'magic' and 'religion' must be made given the "hostility" between the two $(2002,42){ }^{2}$ Durkheim contends that such a distinction can be made by stressing the collective nature of religion $(2002,42)$. This constitutes the second stage of Durkheim's definition: a religion is something "eminently collective" $(2002,46)$.

For Durkheim, the collective nature of 'religion' was a central definitional attribute. $\mathrm{He}$ contended that historically 'religion' had not existed without what he called a 'church', meaning simply a "society whose members are united together because they share a common conception of the sacred world and its relation to the profane world, and who translate this common conception into identical practices" (2002, 42-43). For Durkheim, a church does not require "any official governing body" but is rather simply "a defined group" $(2002,43) .{ }^{3}$ The presence of a church can distinguish religion from mere magic 
Pre-print version of a book chapter accepted for publication by Routledge in Day, A. ed. Religion and the 3 Individual: Belief, Practice, and Identity. Aldershot: Ashgate, pp. 157-168.

since a "church of magic does not exist": "magic does not bind its followers to one another and unite them in a single group living the same life"; there are "no lasting bonds" between the magician and their followers that "make them members of a moral body". (2002, 42-43). Durkheim conceded that his definition precludes individual religiosity. Writing in 1912, he noted that some of his contemporaries had wondered whether "individual religions established by the individual and celebrated for himself alone" were "likely to become the dominant form of religious life" but asked the reader to "leave aside these speculations on the future" and to focus upon "religions as they are in the present and as they have been in the past". (2002, 44-45). However, he did comment that such individual cults did not constitute a different type of religion but "rather the same ideas and the same principles" applied to a different circumstances, focussed on "the life of the individual" rather than the "collectivity as a whole" $(2002,45)$.

Almost a century has passed since Durkheim formulated his definition of religion. It is a subject of intense debate whether religion is still by definition a collective activity or whether it is now a private individual affair. However, reference to law is non-existent in this debate (Hill, 1973, James, 1982). The purpose of the present piece is to examine whether the legal evidence supports Durkheim's assertion that religion is "eminently collective" $(2002,46)$, beginning with international human rights guarantees. As Edge $(2002,29)$ notes, throughout the twentieth century, international law evolved beyond the nineteenth century focus on the relationship between States to the elucidation and protection of international human rights guarantees, which invariably included provisions on religion of various different kinds (see Little, 2002, 35). Of these provisions, Article 18 of the Universal Declaration on Human Rights 1948 (UDHR) may be seen as a "watershed" in that it was the first international treaty which did not conceptualise religion under the umbrella of minority rights (Evans, 1997, 172-173). Rather, religion was protected as a general human right. The Article provides:

Everyone has the right to freedom of thought, conscience and religion; this right includes freedom to change his religion or belief, and freedom, either alone or in community with others and in public or private, to manifest his religion or belief in teaching, practice, worship and observance. 
Pre-print version of a book chapter accepted for publication by Routledge in Day, A. ed. Religion and the 4 Individual: Belief, Practice, and Identity. Aldershot: Ashgate, pp. 157-168.

For Evans, under Article 18, freedom of religion became "bound up with the development of the concept of individual human rights as an object of international legal concern" (1997, 172-173). There are two separate rights under Article 18. The first right is the internal freedom of freedom of thought, conscience and religion - known as the forum internum - this includes the right to hold a religion or belief and to change it. Martínez-Torrón $(2002,104)$ contends that like other human rights, this internal freedom is "primarily an individual right". The second right is the external freedom to manifest religion or belief in worship, teaching, practice and observance - known as the forum externum - this may take place "either alone or in community with others and in public or private". This appears to be recognition of a collective right to religious liberty. However, it can be argued that all this affects is the exercise of the rights: the right to manifest is an individual right which may be exercised individually ("alone") or collectively ("in community with others"). The Article simply recognises the choice of the individual; it does not recognise a collective right to religious liberty as such.

This perception of religion as primarily an individual matter has been further elucidated in relation to Article 9 of the European Convention on Human Rights. Article 9(1) is almost identical to Article 18 UDHR. ${ }^{4}$ Evans $(2001,72)$ contends that Article 9(1) is an individual right since "the emphasis in the interpretation of Article 9 is on the internal: the private thought, conscience and religion of the individual". It does not provide a collective right for religious groups acting as such to manifest their religious liberty (see Evans, 2001, 103). However, despite this, the European Court of Human Rights has heard cases brought by religious groups. For Taylor (2005, 225-226), this does not indicate that Article 9 includes a collective right; rather when such cases are brought it is actually the individual members who are exercising their individual rights collectively. The European Commission for Human Rights has held that Churches are entitled to protection under Article 9 but only through the protection afforded to its individual members, and based upon their either identical or at least substantially similar views. ${ }^{5}$ Collective religiosity is only protected to facilitate the individual's manifestation of religion. ${ }^{6}$ Although Martínez-Torrón $(2002,14)$ has concluded that this means that Article 9 also has “a very significant institutional or 'collective' dimension", it is difficult 
Pre-print version of a book chapter accepted for publication by Routledge in Day, A. ed. Religion and the 5 Individual: Belief, Practice, and Identity. Aldershot: Ashgate, pp. 157-168.

to reconcile this view with the jurisprudence of the international bodies. The way in which Article 9 is framed - as an individual right that which may be exercised with others - means that any collective dimension derives from the individual right. ${ }^{7}$

Other human rights provisions follow this interpretation of Article 9 ECHR and Article 18 UDHR. The text of Article 18 of the International Covenant on Civil and Political Rights (ICCPR) is similar to Article 9; Evans $(2000,46)$ contends that it "permits individuals to act in a fashion which is in accordance with their beliefs if it is linked to a form of worship, teaching or observance". ${ }^{8}$ However, the Human Rights Committee in 1993 commented that "a broad range of acts" were protected by the Article: the reference to "practice" and "teaching" includes "acts integral to the conduct by religious groups of their basic affairs, such as, inter alia, the freedom to choose their own religious leaders, priests and teachers, the freedom to establish seminaries or religious schools and the freedom to prepare and distribute religious texts and publications". 9 This suggests that certain collective rights originate from the individual right on the face of the Article. This is also true of the Declaration on the Elimination of All Forms of Intolerance and Discrimination based on Religion or Belief 1981. Article 1 of the sets out freedom of religion in terms very similar to the Universal Declaration and International Covenant but Article 6, in providing a list of freedoms that are included in this general right, outlines a number of derivative rights which benefit collective religiosity. Under Article 6, freedom of religion includes the right to "worship or assemble in connection with a religion or belief, and to establish and maintain places for these purposes", to "establish and maintain appropriate charitable or humanitarian institutions" and to "establish and maintain communications with individuals and communities in matters of religion and belief at the national and international levels." However, it is clear that these collective rights derive from the individual rights.

Freedom of religion provisions in international human rights treaties invariably influences the corresponding provisions in national constitutions. For example, in 
Pre-print version of a book chapter accepted for publication by Routledge in Day, A. ed. Religion and the 6 Individual: Belief, Practice, and Identity. Aldershot: Ashgate, pp. 157-168.

Finland, section 11 of the 2000 Constitution, which protects freedom of religion, is clearly focussed on the individual bestowing upon individual citizens a number of individual rights and freedoms. ${ }^{10}$ However, the Constitutions of Spain and Italy, for example, protect freedom of religion as both an individual and a collective right. Article 16 of the Spanish Constitution of 1978 proclaims that, "Freedom of ideology, religion and worship of individuals and communities is guaranteed, with no other restriction on their expression than may be necessary to maintain public order as protected by law". The Italian Constitution 1948 protects individual religious freedom under Article 19 (which bestows upon every citizen the right to "profess faith freely" and to "exercise worship in public or private, provided that the rites involved do not offend common decency") and collective religious freedom under Articles 7 and $8 .{ }^{11}$

This is also the position with regard to constitutional law in England and Wales. By virtue of the Human Rights Act 1998, the individual right to religious liberty found in Article 9 ECHR is now part of English law. However, due to lobbying by religious groups during the passage of the Human Rights Bill through Parliament (see Edge, 2002, 85), the Human Rights Act 1998 also includes a special provision recognising the Convention rights of religious organizations under section 13. Section 13 serves as a "specific recognition of religious group autonomy" (Ahdar and Leigh, 2005, 327); it involves only collective, and not individual, religious liberty (Rivers, 2000, 138). It reads:

(1) If a court's determination of any question arising under this Act might affect the exercise by a religious organisation (itself or its members collectively) of the Convention right to freedom of thought, conscience and religion, it must have particular regard to the importance of that right.

(2) In this section 'court' includes a tribunal.

Section 13 seems to recognise a collective right to freedom of thought, conscience and religion, which courts should have "particular regard" for. However, commentators seem divided as to the significance of the section. For Rivers (2001, 227), the section means that an "interesting collective religious liberty will prevail" over competing interests but Cumper (2000) contends that section 13 is merely a symbolic political statement designed to placate religious opponents. Judicial decisions to date suggest that Ahdar and Leigh (2005, 359) may be accurate in calling the provision "rather mild". Section 13 aside, 
Pre-print version of a book chapter accepted for publication by Routledge in Day, A. ed. Religion and the 7 Individual: Belief, Practice, and Identity. Aldershot: Ashgate, pp. 157-168.

there are other examples of how English constitutional law may regard religion as a collective right. By dint of the established status of the Church of England (for details, see Doe, 1996, Hill, 2001 and Sandberg, 2006a), certain rights are enjoyed by virtue of being resident in a Church of England parish. In the words of Say (1991), "every citizen resident in the parish has, regardless of their own religious commitment or lack of it, a rightful claim upon their parish priest". This extends to a broad right to attend public worship, ${ }^{12}$ to receive Holy Communion unless there is a lawful excuse for denial, ${ }^{13}$ and to be married and buried in the Parish Church. ${ }^{14}$ It is unclear whether such rights are individual rights attached to individual parishioners or collective rights in that they arise by virtue of collective residence in a parish. It is clearer that the exercise of these rights is collective: the resulting rites are all exercised in groups. The fact that English law effectively provides for public access to these rites infers that it sees religion, at least in the guise of the established church, as something that is exercised collectively.

Such collective rights are common in countries where there is a State Church. For example, Article 4 of the Danish Constitution of 1849, as amended in 1953, states that "The Evangelical Lutheran Church shall be the Folk Church of Denmark, and as such shall be supported by the State". This provides a collective right to the Church for special treatment. Moreover, in some jurisdictions, the constitution may favour the State Church by imposing a collective burden upon members. An example of this may be found in section 7 of the Church of Sweden Act 1998, which states that, "Members of the Church of Sweden shall pay a local and a regional church fee". Such provisions clearly indicate a perception that religion is a collective phenomenon: the collective practice of religion is recognised by the State and the State imposes upon members a duty to finance it. By contrast, other constitutions reveal a view that freedom of religion is neither a collective nor an individual right. Article 13 of the Greek Constitution, states that, "Freedom of religious conscience is inviolable. The enjoyment of civil rights and liberties does not depend on the individual's religious beliefs". This infers that the right is not directed to religious believers as individuals or religious groups as collectives; rather, the right is free-standing and simply exists. 
Pre-print version of a book chapter accepted for publication by Routledge in Day, A. ed. Religion and the 8 Individual: Belief, Practice, and Identity. Aldershot: Ashgate, pp. 157-168.

The recent history of the Irish Constitution shows a move from a collective right to a right which although individual in part is actually directed not at human individuals or collectives but rather at the divine. Article 44 of the 1937 Constitution formerly provided a collective right in that it provided that "the state recognises the special position of the Holy Catholic Apostolic and Roman Church as the guardian of the Faith professed by the great majority of citizens". However, Article 44(2) now provides an individual right, stating that "Freedom of conscience and the free profession and practice of religion are, subject to public order and morality, guaranteed to every citizen". This is preceded by Article 44(1) which casts freedom of religion not as a human right but rather as homage to God, providing, "The State acknowledges that the homage of public worship is due to Almighty God. It shall hold His Name in reverence, and shall respect and honour religion". Although the Constitutional Review Group in 1996 called for Article 44.1 to be replaced by the phrase "The State guarantees to respect religion", this has not been put to the people (Colton 2006: p.97). If the change was implemented, it would be uncertain whether the phrase "The State guarantees to respect religion" sees 'religion' as a collective phenomena, a private affair or as a duty to the divine.

Expanding the focus away from the key constitutional instruments reveal numerous ways in which laws see religion as both an individual and a collective affair. Laws from England and Wales may serve as an example. There are a number of laws in England and Wales which extend legal to protection to religious groups. On the surface these laws suggest a perception of religion as a collective activity. An obvious example would be laws which provide special treatment for religious groups and organisations. Legal preference is awarded to the collective manifestation of religion. There are a number of criminal offences which outlaw hostility or hatred towards religious groups. A crime is "racially or religiously aggravated" (and consequentially punished by a tougher sentence) where there is "hostility towards members of a racial or religious group based on their membership of that group". ${ }^{15}$ A defendant is guilty of an offence under the Racial and Religious Hated Act 2006 if he stirs up "hatred against a group of persons defined by reference to religious belief or lack of religious belief". ${ }^{16}$ In both cases, the criminal law only protects religious individuals if they are members of a collective. A further example 
Pre-print version of a book chapter accepted for publication by Routledge in Day, A. ed. Religion and the 9 Individual: Belief, Practice, and Identity. Aldershot: Ashgate, pp. 157-168.

can be found in the exemptions religious groups enjoy from discrimination law. For example, under the Sex Discrimination Act 1975, it is illegal to discriminate on grounds of sex. However, "organised religions" have an exemption under section 19: they may lawfully require employees to be of a particular sex, for example, if that requirement is imposed "so as to comply with the doctrines of the religion", or "because of the nature of the employment and the context in which it is carried out, so as to avoid conflicting with the strongly-held religious convictions of a significant number of the religion's followers". This is clearly a collective right; although if it is exercised for the second reason, it is a collective right exercised on behalf of a "significant number" of individuals who belong to the collective. ${ }^{17}$

A further example of how the law recognises religion as a collective force can be found in the preferential legal treatment for places of worship. ${ }^{18}$ Such privileges for places of worship cannot be read as rights for individual members or for individual citizens since the preferential treatment of such buildings does not give rise to an individual right to use such buildings as places or worship or as buildings of historical or architectural interest. ${ }^{19}$ However, the legal protection of worship does not infer a perception that religion is a collective force since English law does not distinguish between collective or individual worship; ${ }^{20}$ the House of Lords has recognised that worship may be communal or personal. ${ }^{21}$ A final example of legal protection of religion as collective phenomenon may be found in legal statements that underline the perceived societal benefits of religion. However, although they seem to suggest the collective nature of religion by emphasizing the public benefit of religion, ${ }^{22}$ this is not necessarily evidence that the courts see religion as a collective phenomenon since courts have stressed that the public benefit derives from the fact that it beneficial for individuals to have a religion. ${ }^{23}$ Although the black letter of the law seems to be recognising the collective nature of religion, a closer examination shows that it is simply the recognition of the individual right to religious liberty expressed in close association.

In addition to these laws, which seem to protect religious groups, there are also numerous laws in England and Wales which protect religious believers and seem to infer that 
Pre-print version of a book chapter accepted for publication by Routledge in Day, A. ed. Religion and the 10 Individual: Belief, Practice, and Identity. Aldershot: Ashgate, pp. 157-168.

religion is an individual matter. Indeed, a recent House of Lords decision explicitly characterised religion as an individual matter. For Lord Nicholls:

Religious and other beliefs and convictions are part of the humanity of every individual. They are an integral part of his personality and individuality. ${ }^{24}$

English law mirrors this understanding of religion by providing free-standing legal rights for believers, epitomised by the 'conscience clause' which exempts the individual from a generally applicable law on grounds of their conscientious objection. ${ }^{25}$ Other legal rights are bestowed upon the individual on grounds of their 'religion'. For example, section 1 of the Adoption and Children Act 2002, in common with various other statutes regarding the care of children, recognises the right of children to have "due consideration" to be given to their "religious persuasion". A further example is section 139 of the Criminal Justice Act 1988, which provides that it is a defence to carry an article with a blade "for religious reasons". This provision provides for the exemption of the Sikh Kirpan but is drafted broadly so that the exemption is not dependent upon membership of the collective but is an individual right. Other legal rights are bestowed upon the individual on grounds of 'religion' such as those provided by the Human Rights Act 1998 and the new law on religious discrimination. ${ }^{26}$ Such rights are not dependent upon individuals being a member of a particular collective but are dependent on individuals being aligned with a religion. It might be suspected that those who are part of a collective will find this requirement easier to meet. Indeed, if the State's conception of religion is narrowly defined so that only known collective religions are protected, then these rights, though addressed to the individual, become collective rights.

Indeed, a number of seemingly individual rights are actually collective rights since they are only bestowed upon individuals by virtue of their membership of a collective. For example, although Sikhs working on a building site are exempt from the normal rule requiring the wearing of safety hats, this right is not an individual right since the exemption in section 11 of the Employment Act 1989 cannot be relied upon by those who are not members of the Sikh faith. Exemptions from normal slaughter rules to permit religious methods are also rights dependent upon membership of the collective: they only apply to licensed Muslims or Jews who use Jewish or Muslim methods for the food of 
Pre-print version of a book chapter accepted for publication by Routledge in Day, A. ed. Religion and the 1 Individual: Belief, Practice, and Identity. Aldershot: Ashgate, pp. 157-168.

Jews or Muslims. ${ }^{27}$ However, where a right is conferred only upon those who are not members of a religious collective, such a right is clearly an individual right since those who are granted the right are not members of a collective and are defined by their lack of membership. A rare example of such a right may be found in section 1 of the Oaths Act 1978 which provides that anyone who is "neither a Christian nor a Jew" does not have to take the oath in the prescribed form provided that they take it "in any lawful manner".

It is clear that the legal evidence represents a recognition that religion is both an individual and collective phenomenon. Although human rights instruments are phrased as individual rights and are directed at individuals, they have some effect upon religious collectives. Furthermore, although international human rights guarantees colour provisions on religion in national constitutions, many such constitutions stress the collective rights of religious organisations. This is true in not only in countries where there is a State Church such as England and Denmark but is also in other jurisdictions, such as Spain and Italy. Laws in England and Wales which defend religious groups and religious believers indicate that religion is protected both as a collective activity and as a key element of personal identity. Legal provisions seemingly protecting religious groups often have the purpose of protecting the individuals who make up such groups. Provisions which seem to protect the individual are often dependent on that individual being a member of a collective or designated as religious in some other way. This lack of a clear distinction between individual and collective rights may be interpreted as showing that Durkheim was correct. Collectivity remains a definitional attribute of religion: the law has not fully embraced the idea that religion is an individual and private affair. Moreover, the legal evidence supports the Durkheimian premise that individual cults do not constitute a different type of religion: the legal evidence suggests an understanding of religion as a phenomenon which has both a collective and an individual dimension. More broadly, this exploratory examination serves as a case study to illustrate how the study of law and legal mechanisms may enrich a sociological understanding of religion (Doe, 2004, Sandberg, forthcoming).

\section{Bibliography}


Pre-print version of a book chapter accepted for publication by Routledge in Day, A. ed. Religion and the 12 Individual: Belief, Practice, and Identity. Aldershot: Ashgate, pp. 157-168.

Ahdar, R, and Leigh, I, 2005, Religious Freedom in the Liberal State, Oxford: Oxford University Press

Colton, P, 2006, 'Religion and Law in Dialogue: Covenantal and Non-Covenantal Cooperation of State and Religions in Ireland' in Puza, R and Doe, N (eds), Religion and Law in Dialogue: Covenantal and Non-Covenantal Cooperation between State and Religion in Europe, Peeters: Leuven

Cumper, P, 2000, 'The Protection of Religious Rights under Section 13 of the Human Rights Act 1998 [2000] Public Law 265

Doe, N, 1996, The Legal Framework of the Church of England, Oxford: Clarendon

Doe, N, 2004, 'A Sociology of Law on Religion - Towards a New Discipline: Legal Responses to Religious Pluralism in Europe' 152 Law and Justice 68

Durkheim, E, 2001, The Elementary Forms of Religious Life, Oxford: Oxford University Press

Edge, P W, 2002, Legal Responses to Religious Difference, The Hague: Knuwler Law

Evans, C, 2001, Freedom of Religion under the European Convention on Human Rights Oxford: Oxford University Press

Evans, MD, 1997, Religious Liberty and International Law in Europe, Cambridge: Cambridge University Press

Evans, MD, 2000, 'The UN and Freedom of Religion' in Ahdar, RJ (ed), Law and Religion, Aldershot: Ashgate p.46

Hare, I, 2006, 'Crosses, Crescents and Sacred Cows: Criminalising Incitement to Religious Hatred' [2006] Public Law 521

Hill, M, 1973, A Sociology of Religion, London: Heinemann

Hill, M, 2001, Ecclesiastical Law, Oxford: Oxford University Press

Hill, M and Sandberg, R, 2006 , 'Muslim Dress in English Law: Lifting the Veil on Human Rights' 1 Religión y Derecho (Law and Religion) 302

Idinopulos, TA, and Wilson, BC (ed), 1998, What is Religion?: Origins, Definitions \& Explanations, Leiden: Brill

James, W, 1982, The Varieties of Religious Experience, New York: Penguin 
Pre-print version of a book chapter accepted for publication by Routledge in Day, A. ed. Religion and the 13 Individual: Belief, Practice, and Identity. Aldershot: Ashgate, pp. 157-168.

Little, D, 2002, 'Religious Minorities and Religious Freedom' in Danchin, PG and Cole, EA (eds), Protecting the Human Rights of Religious Minorities in Eastern Europe Columbia: Columbia University Press

Martínez-Torrón, J, 2002, 'Religious Liberty in European Jurisprudence' in Hill, M, (ed) Religious Liberty and Human Rights, Cardiff: University of Wales Press

Platvoet, JG and Molendijk, AL (ed), 1999, The Pragmatics of Defining Religion: Contexts, Concepts \& Contests, Leiden: Brill)

Rivers, J, 2000, 'From Toleration to Pluralism: Religious Liberty and Religious Establishment under the United Kingdom's Human Rights Act' in Ahdar, R, (ed) Law and Religion, Aldershot: Ashgate 138

Rivers, J, 2001, 'Religious Liberty as a Collective Right' in O'Dair, R, and Lewis, A, (ed) Law and Religion, Oxford: Oxford University Press

Sandberg, R, 2006a 'The Legal Status of Religious Denominations and State-Church Relations in the UK' in Droit des Religions en France et en Europe: recueil de Textes Bruxelles: Bruylant

Sandberg, R, 2006b, 'A Whitehall Farce? Defining and Conceptualising the British Civil Service’ [2006] Public Law 653

Sandberg, R, forthcoming, 'Religion, Society and Law: An Analysis of the Interface Between Law on Religion and the Sociology of Religion', Doctoral thesis, Cardiff University.

Say, D, 1991, 'Towards 2000: Church -State Relations' 2 (8) Ecclesiastical Law Journal 152

Taylor, PM, 2005, Freedom of Religion: UN and European Human Rights Law and Practice, Cambridge: Cambridge University Press

Weber, M, 1965, Sociology of Religion, London: Methuen

\footnotetext{
${ }^{1}$ However, the difference between Weber and Durkheim should not be over-stated. Durkheim recognised that such a preliminary definition would be limited. He noted that "the underlying and truly revealing features of religion" can only be determined "at the end of our inquiry".

2 "Magic takes a kind of professional pleasure in profaning holy things" and that although "religion has not always condemned and prohibited magical rites, it generally views them with disfavour" $(2002,42)$.

${ }^{3}$ This is questionable: who defines the group? Surely the group is defined by some official body, whether itself or the State.
} 
Pre-print version of a book chapter accepted for publication by Routledge in Day, A. ed. Religion and the 14 Individual: Belief, Practice, and Identity. Aldershot: Ashgate, pp. 157-168.

\footnotetext{
${ }^{4}$ It provides: "Everyone has the right to freedom of thought, conscience and religion; this right includes freedom to change his religion or belief, and freedom, either alone or in community with others and in public or private, to manifest his religion or belief, in worship, teaching, practice and observance."
}

${ }^{5} X v$ Denmark (1976) 5 ECHR 157 See also $X$ and the Church of Scientology v Sweden (1979) 16 D\&R 68.

${ }^{6}$ Thus, denying legal recognition entirely to certain religious groups has been held to violate freedom of religion (Metropolitan Church of Bessarabia v Moldova (2002) 35 EHRR 306).

${ }^{7}$ Article 9(2) does provide a collective right but this is a collective right for the State to limit the individual's right to manifest if prescribed conditions are met. It reads: "Freedom to manifest one's religion or beliefs shall be subject only to such limitations as are prescribed by law and are necessary in a democratic society in the interests of public safety, for the protection of public order, health or morals, or the protection of the rights and freedoms of others."

${ }^{8}$ Emphasis added.

${ }^{9}$ Human Rights Committee General Comment 22 of 1993, para 4

${ }^{10}$ It provides: "Everyone has the freedom of religion and conscience. Freedom of religion and conscience entails the right to profess and practice a religion, the right to express one's convictions and the right to be a member of or decline to be a member of a religious community. No one is under the obligation, against his or her conscience, to participate in the practice of a religion."

${ }^{11}$ Article 7 is concerned with the Catholic Church, providing that, "The State and the Catholic Church are, each according to its own order, independent and sovereign". Article 8 is concerned with all religious groups other providing that "all denominations are equally free before the law" and that such denominations have the right to organise themselves provided that they do not conflict with the Italian legal system.

${ }^{12}$ Cole v PC [1937] 1KB 316

${ }^{13}$ Sacrament Act 1547, section 8

${ }^{14}$ Argar v Holdsworth (1758) 2 Lee 515; Kemp v Wickes (1809) 3 Phil Ecc 26; Burial Law Amendments Act 1880

${ }^{15}$ Section 28 of the Crime and Disorder Act 1998 as amended by the Anti-Terrorism, Crime and Security Act 2001. Note that this only applies to certain crimes: see sections 29-32 of the Crime and Disorder Act 1998.

${ }^{16}$ The Act creates six new offences. To be charged with any offence, the words, behaviour, written material or recordings or programme must be threatening, and there must be an intention to stir up religious hatred: see Hare (2006)

${ }^{17}$ Other exceptions for religious groups are provided by laws outlawing discrimination on grounds of religion or belief. In the context of employment, there is an exemption where being of a particular religion or belief is "a genuine occupational requirement for the job" and that "it is proportionate to apply that requirement in the particular case" (Employment Equality (Religion or Belief) Regulations 2003, regulation $7(3)$ ). In the context of goods and services, there are broad exemption for organisations "relating to religion or belief", religious charities and faith schools (Equality Act 2006, sections 57-59). 
Pre-print version of a book chapter accepted for publication by Routledge in Day, A. ed. Religion and the 15 Individual: Belief, Practice, and Identity. Aldershot: Ashgate, pp. 157-168.

${ }^{18}$ For example, section 60 of the Planning (Listed Buildings and Conservation Areas) Act 1990 provides an exemption for "any ecclesiastical buildings which is for the time being used for ecclesiastical purposes". Further examples include the Ecclesiastical Exemption (Listed Buildings and Conservation Areas) Order 1994 (SI 1994/1771) and section 11 of the Local Government Finance Act 1988.

${ }^{19}$ Cole v Police Constable 443A[1937] 1 KB 316

${ }^{20}$ See the leading case of $R v$ Registrar General, ex parte Segerdal [1970] 3 All ER 886. For Lord Denning MR, "Religious worship means reverence or veneration of God or of a supreme being" whilst Buckley LJ defined worship as "something which must have some, at least, of the following characteristics: submission to the object worshipped, veneration of that object, praise, thanksgiving, prayer or intercession".

${ }^{21}$ See the comments of Lord Nicholls in $R v$ Secretary of State for Education ex parte Williamson [2005] UKHL 15: "To a greater or lesser extent adherents are required or encouraged to act in certain ways, most obviously and directly in forms of communal or personal worship, supplication and meditation".

${ }^{22}$ To be recognised as charity 'for the advancement of religion', the purpose must have a public benefit. Historically, it has been presumed that all religious charities have a public benefit. However, under the Charities Act 2006, religions must prove this. It has been suggested that most religious charities will have no difficulty doing so. See, for example, the comments of Edward Miliband at second reading in the House of Commons on the $26^{\text {th }}$ June 2006: "making provision for people to attend acts of worship is clearly a public benefit." This has been recognized by the courts: in Neville Estates v Madden [1962] Ch 832, Cross J noted that courts was "entitled to assume that some benefit accrues to the public from the attendance at places of worship of persons who live in this world and mix with their fellow citizens".

${ }^{23}$ This 'bottom-up' approach can be found in the words of Lord Simmonds in Gilmour v Coates [1949] AC 426: "The law of England ... assumes that it is good for man to have and to practise a religion."

${ }^{24} R v$ Secretary of State for Education ex parte Williamson [2005] UKHL 15

${ }^{25}$ See, for example, section 4 of the Abortion Act 1967: "no person shall be under any duty, whether by contract or by any statutory or other legal requirement, to participate in any treatment authorised by this Act to which he has a conscientious objection".

${ }^{26}$ Under the Employment Equality (Religion or Belief) Regulations 2003 and part 2 of the Equality Act 2006, it is unlawful for A to discriminate against B on grounds of religion or belief, for example.

Developments in discrimination law and human rights law are discussed by Hill and Sandberg (2006)

${ }^{27}$ Welfare of Animals (Slaughter or Killing) Regulations 1995 